\title{
Ceraunus Blue Butterfly, Hemiargus ceraunus (Fabricius) (Insecta: Lepidoptera: Lycaenidae) 1
}

Jaret C. Daniels ${ }^{2}$

\section{Introduction}

The ceraunus blue butterfly, Hemiargus ceraunus (Fabricius), is a widespread Neotropical butterfly common in southern portions of the United States. It is common in various open, sunny habitats including roadsides, fallow agricultural land, weedlots, utility corridors, scrubs, open woodlands, yards and parks.

\section{Distribution}

The ceraunus blue occurs across much of the extreme southern United States southward through Mexico, Central America and the West Indies to South America; occasionally strays northward. In Florida, it can be found in all 67 counties. It is common year-round in southern portions of the state.

\section{Description}

Adults: The ceraunus blue butterflies are small and easy to overlook. Adults have a wingspan range of 22 to $30 \mathrm{~mm}$. The sexes are dimorphic. The upper surface of the wings is lavender-blue in males with a narrow black margin and a single black hindwing spot. Females are somewhat darker with blue scaling limited to the wing bases. The undersides of the wings are gray with dark bars, white bands and white-rimmed black spots. The hindwing has a prominent orange-rimmed black marginal spot.

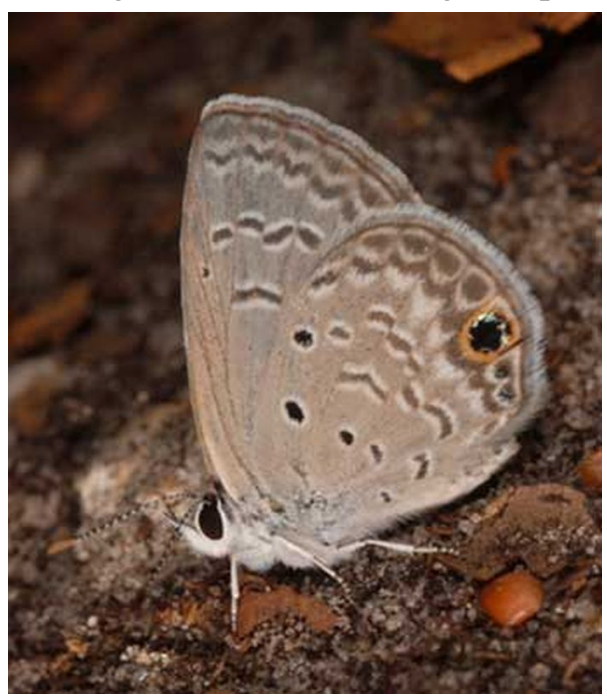

Figure 1. Adult ceraunus blue butterfly, Hemiargus ceraunus (Fabricius). Credits: Jaret C. Daniels, University of Florida

1. This document is EENY-425, one of a series of Featured Creatures from the Entomology and Nematology Department, Florida Cooperative Extension Service, Institute of Food and Agricultural Sciences, University of Florida. Published: February 2009. This document is also available on Featured Creatures Website at http://creatures.ifas.ufl.edu. Please visit the EDIS Website at http://edis.ifas.ufl.edu. Additional information on these organisms, including many color photographs, is available at the Entomology and Nematology Department website at http://entnemdept.ifas.ufl.edu/.

2. Jaret C. Daniels, assistant professor, Entomology and Nematology Department, Institute of Food and Agricultural Sciences, University of Florida, Gainesville, FL 32611.

The Institute of Food and Agricultural Sciences (IFAS) is an Equal Opportunity Institution authorized to provide research, educational information and other services only to individuals and institutions that function with non-discrimination with respect to race, creed, color, religion, age, disability, sex, sexual orientation, marital status, national origin, political opinions or affiliations. U.S. Department of Agriculture, Cooperative Extension Service, University of Florida, IFAS, Florida A. \& M. University Cooperative Extension Program, and Boards of County Commissioners Cooperating. Millie Ferrer, Interim Dean 
Larvae: The slug-like larvae are highly variable and range in color from light green to pinkish-red.

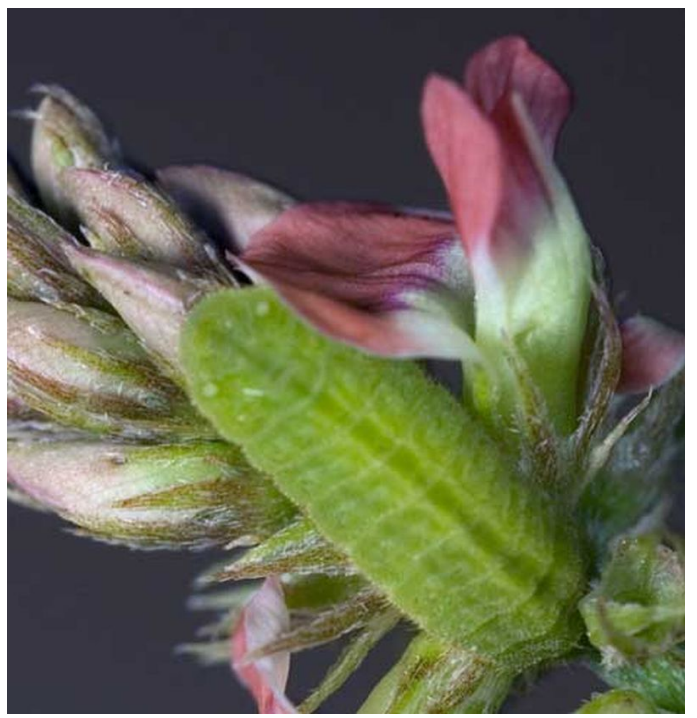

Figure 2. Green larva of the ceraunus blue butterfly, Hemiargus ceraunus (Fabricius), on indigo (Indigofera spp.) (Fabaceae). Credits: Jaret C. Daniels, University of Florida

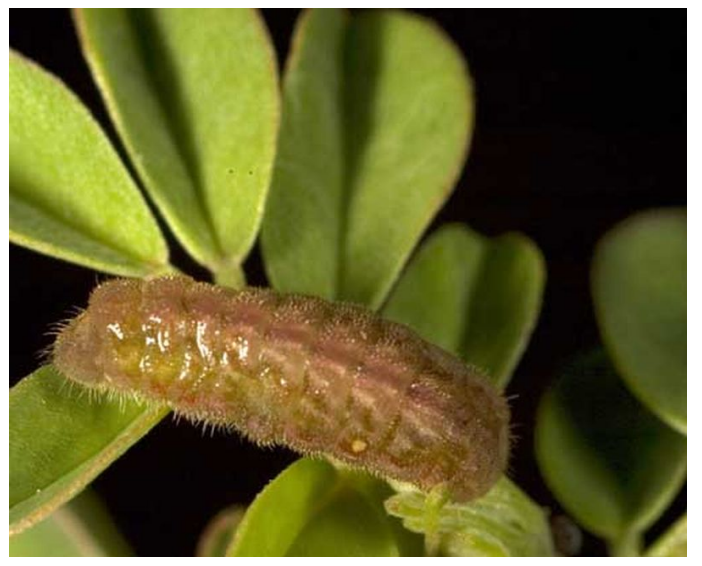

Figure 3. Red larva of the ceraunus blue butterfly, Hemiargus ceraunus (Fabricius), on indigo (Indigofera spp.) (Fabaceae). Credits: Jaret C. Daniels, University of Florida

Pupae: The pupae are yellow-green.

\section{Life Cycle}

The ceraunus blue produces multiple generations each year. Adults may be found in all months of the year in southern Florida. Adults fly very low to the ground just above the vegetation. Females lay the small, somewhat flattened blue eggs singly on flower buds of a variety of herbaceous legumes. Larvae feed on the new growth, buds and flowers of the host plant.

\section{Hosts}

Hosts include a variety of herbaceous legumes: including rosary pea, Abrus precatorius L.; partridge pea, Chamaecrista fasciculata (Michx.) Greene; sensitive pea, Chamaecrista nictitans (L.) Moench; and indigo, Indegofera spp..

\section{Selected References}

Cech R, Tudor G. Butterflies of the East Coast: An Observer's Guide. 2005. Princeton University Press, Princeton, NJ. 345 pp.

Daniels JC. Butterflies of Florida Field Guide. 2003. Adventure Publications, Cambridge, MN. 250 pp.

Daniels JC. 2000. Butterflies 2: Butterflies of the Southeast. UF/IFAS. Card Set. SP 274.

Kimball CP. 1965. The Lepidoptera of Florida; an annotated checklist. Arthropods of Florida and Neighboring Land Areas Vol. 1. Florida Department of Agriculture and Consumer Services, Division of Plant Industry. 363 pp.

Minno MC, Butler JF, Hall DW. 2005. Florida Butterfly Caterpillars and Their Host Plants. University Press of Florida, Gainesville. 341 pp.

Minno MC, Emmel TC. 1993. Butterflies of the Florida Keys. Scientific Publishers, Gainesville. 168 pp. 